\title{
The indigenous Afrikaans film: Representation as a nationalistic endeavour
}

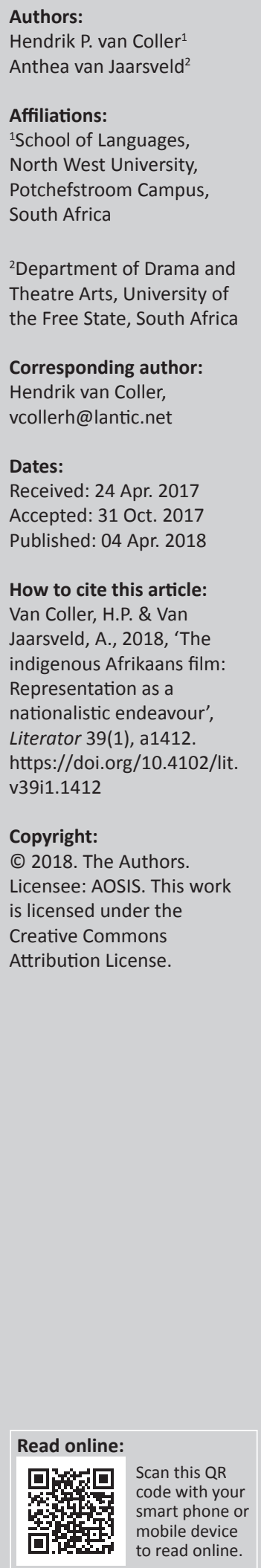

Within the South African context, Afrikaans films unabashedly and predominantly served Afrikaner nationalism. Given the South African historical and political background, it is evident that Afrikaner nationalism has almost become an obscene term because of its association with the National(ist) Party and its apartheid policy: emblematic of an ideology and policy that has been rejected worldwide and has even been compared - albeit a skewed comparison - to National Socialism. In this article, the different stages that emancipation of a formerly colonised literature goes through, according to Amuta (1989), Ashcroft (1989) and Brink, will be discussed in detail with reference to the Afrikaans films, Geboortegrond (1946) and Hans die skipper (1952). In this process of representation, the historical past is re-assessed and laid to rest with far-reaching philosophical, ideological and poetical implications. In order to discuss the representation of this contextually bound discourse, mention will be made regarding important relevant theoretical concepts such as semiotics, discursive formations, literary reception and processing, reportorium, horizon of expectation and habitus.

\section{Introductory remarks: The evolution of post-colonial literatures}

Martin Botha (2012) asserted in his overview of South African films that Afrikaans films, especially in their initial phase, unabashedly and predominantly served Afrikaner nationalism. This assertion is validated by the fact that a nationalistic endeavour in any colonised literature (and culture) is almost a sine qua non as Amuta (1989) and Ashcroft (1989) have explicated in their independent discussion of post-colonial literatures. Our assumption is that this model can mutatis mutandis be applied to the evolution of the Afrikaans film. Brink (1991) employed their theory in his own description of the evolution of Afrikaans literature. This model illustrates that the emancipation of a formerly colonised literature undergoes different stages. The initial stage is that of appropriation of the themes, models and even authors of the former colonial power. The second stage is that of an aggressive nationalism followed by a stage of (initial) emancipation, 'restructuring European "realities" in post-colonial terms, not simply by reversing the hierarchical order, but by interrogating the philosophical assumptions on which the order was based' (Ashcroft 1989:33).

Although Amuta, Ashctroft and Brink in their wake only discern three stages, a final stage could be that of total emancipation where the initiative no longer lies with other literatures and cultures (and even the underlying philosophical assumptions), but where the own literary tradition is scrutinised, re-evaluated and even parodied. In the process, the historical past is re-assessed and laid to rest with far-reaching philosophical, ideological and poetical implications. ${ }^{1}$ When the evolution of the Afrikaans film is closely examined (cf. Van Nierop 2016), it becomes clear that this evolution fits into the model of Amuta, Ashctroft and Brink with the notable exception of the first stage (that of appropriation). This is clearly because of the fact that the first Afrikaans literary texts were published in the latter half of the 20th century and that the first films by contrast were mainly produced in the 1930s when Afrikaans nationalism flourished.

The two films under discussion clearly belong to the second phase mentioned above. Hans die Skipper was released in 1929 and still adheres to the ideals of literary critics like E.C. Pienaar that Afrikaans literature should be an expression of Afrikaner nationalism. Geboortegrond (1946), on the other hand, is not a film adaption of an existing novel, but it epitomises all the important traits of the plaasroman (farm novel) - to such an extent that it could be called the

1.The Afrikaans and Dutch term poëtika has nothing to do with poetry but means an individual or collective aesthetics or 'view' of the literary work of art or of writing as such. When describing and assessing Afrikaans literature (and film) in its historical evolution, one not only can discern successive phases or periods but also successive aesthetics ('poëtikas'). 
film adaptation of a non-existing (generic) farm novel. As will be shown later, this sub-genre, which is one of the most important genres in Afrikaans literature, is imbued with nationalistic ideas.

\section{Afrikaner nationalism in a historical context}

When examining the way in which Afrikaner nationalism was propagated in Afrikaans literature and film in 'the initial phase', one has to take into account the social and political position of Afrikaners during the first few decades of the 20th century in South Africa as well as the 'nationalistic' agenda of Afrikaner politicians. What also needs to be considered is that representation as a cultural phenomenon is infinitely more complex than the mere rendering of 'reality' - or even an idealised view thereof - and is deeply embedded in what Bourdieu (1986) termed the 'cultural (or literary) field'. The question one needs to pose as an academic within a postcolonial paradigm is not whether the Afrikaans film served Afrikaner nationalism in the initial phase of its development, but rather 'how'.

Giliomee (2004:306-354) gives a stirring account of the Afrikaners in the aftermath of the devastating Second Anglo Boer War (1899-1902). A deeply divided South Africa unified in 1910 and leaders strove to heal the divide between Englishspeaking South Africans and Afrikaners; black South Africans and their aspirations were discounted or entirely neglected. As far as the Afrikaners were concerned, the majority of people in the two former Boer republics were in dire straits, trying to salvage something out of the ruins of their destroyed farms and farmsteads. In part, the challenge laid in attempting to rekindle lost pride by instilling a renewed sense of nationalism. Other challenges included economic empowerment, cultivation of their own culture and language and, in particular, the quest for a modern Afrikaner identity. This meant coming to terms with and conquering the city, the centre of economic activity par excellence. The Afrikaner never really made peace with the city, and so unsurprisingly, the city is portrayed negatively in Afrikaans novels prior to 1960 (cf. Van Coller 2005). In this process of negative representation of the city, an important role was played by Afrikaner writers (and film producers). The literature of the first decades was predominantly steeped in nationalism or chauvinistic nationalism. Even apparently dissonant voices such as those of C. Louis Leipoldt ("n Nuwe liedjie op 'n ou deuntjie'; 'In die konsentrasiekamp') and Toon van den Heever ('Die beeld van oom Paul') wrote poetry that may be interpreted as nationalistic. The notable exception is most probably Eugene Marais, who befriended several prominent English warmongers during the Second Anglo Boer War (cf. Van der Merwe 2015). N.P. van Wyk Louw, one of the socalled Dertigers (the movement of the 1930s), was initially tentative about nationalism in the 1930s, but advocated a 'liberal nationalism' in the 1950s. This form of nationalism had a tolerant flavour that also accepted other emerging nationalisms.

\section{The Afrikaans plaasroman (farm novel) as a seminal literary genre imbued with nationalistic values}

In this nationalistic phase, the plaasroman (farm novel) was an important literary sub-genre imbued with the myths of the pioneer and the farm as idyllic space. The farm is not only space; it is place, conquered and civilised, giving one right of tenure and - because of lineal consciousness (cf. Coetzee 1985, 1988) - an inalienable space that must be inherited successively by the eldest son. No wonder patriarchal values were dominant within this sub-genre; concretised by photographs of patriarchs, the naming of children according to decorum (the eldest son after his grandfather on father's side; the eldest daughter after her grandmother on mother's side), inherited objects like furniture and even graveyards where forebears were buried. The farm bore witness to social hierarchy because bywoners (sub-farmers) and labourers had neither inherited rights nor any form of tenure. Within this 'mythical space', labour was glorified and romanticised [as in the case of (neo-) marxist social realism] as a means of social mobilisation and progress (cf. Van Coller 2009:11-22; 107-122). It is therefore no surprise that the typical Afrikaans plaasroman (e.g. Somer by C.M. van den Heever) reflects a strange mixture of realism and romanticism. Usually, the realistic mode 'is clearly associated with the bourgeoisie and the coming into being of bourgeois daily life [Sartre argued that] mimesis is always at least tangentially critical: holding up a mirror to nature' (Jameson 2013:5). When something is idealised, however, the mirror has to be distorted.

\section{Representation ${ }^{2}$ as a historical challenge}

If one wants to describe the functioning of the Afrikaans novel (and the Afrikaans film with its rural background) of the early decades of the 20th century and its social and political implications, one should heed the warning of Edward Said (Auerbach 2013):

In order to understand a humanistic text, one must try to do so as if one is the author of that text, living the author's reality, undergoing the kind of life experiences intrinsic to his or her life, and so forth, all by that combination of erudition and sympathy that is the hallmark of philological hermeneutics. (p. v)

This is not historicism (Wellek 1970:151), but rather a 'reconstructionist perspectivism' to coin a phrase, the ability to develop a morphological reconstruction of the past and yet to realise at the same time that an untainted historical view is impossible; one is always affected by what Foucault (1972) has called a 'discursive formation'. One is caught up in a time frame and an ideological and political paradigm that hampers and even disallows objectivity. Foucault and the New Historicists believe that an accurate reconstruction of the past is not possible

2.On a micro level, representation is the realistic portrayal of 'workaday life" in order to (re)construct a historical period in a plausible way on a macro level. 
because such an analysis is always limited by their commitment to the immediate socio-historical context in which they find themselves (Montrose 1989:23).

There is thus a neo-positivistic, deterministic trait in the writings of Foucault (1970) when one scrutinises his views on epistemes (world views). In his introduction to The order of things: An archeology of the human sciences, he postulates that our thoughts are regulated by our historical position, embedded in what he calls a discursive formation of which the individual is usually oblivious (cf. Ankersmit 1986:256). What we regard as truth is actually a result of discursive practices determined by the episteme; almost like normal scientific endeavours are regulated by a paradigm.

Representation is therefore not 'neutral' and never the socalled 'objective' representation of a stable and independent reality. What is represented in the films that we will interpret is not 'truth' or 'reality'. Instead, representation should be explored 'only within the precincts of the contexts or situations or paradigms or communities that give them their local and changeable shape' (Fish 1989:350). What is also important is that it is particularly difficult to imagine oneself within another episteme: 'to twentieth-century eyes, the whole network of similitudes [of the Renaissance episteme] is rather confused and tangled' (Foucault 1994:269-278). Although the first few decades of the 20th century do not constitute a different episteme within Foucault's reasoning, they are so far removed ideologically speaking from the present South Africa that interpretation can easily be distorted.

It is also important to take into account another of Said's statements as a guiding principle:

The meaning of events cannot be grasped in abstract and general forms of cognition [...] the material needed to understand it must not be sought exclusively in the upper strata of society and its major political events but also in art, economy, material and intellectual culture, in the depths of the workaday world and its men and women ... (Said 2013:xx)

A scrutiny of Afrikaans literature and films (and their contents: the representation of 'the workaday world') will most probably give more insight into Afrikaner nationalism than yet another stereotypical description.

\section{Meaning as the result of representational systems ('languages')}

Stuart Hall (1997:2) defines 'culture' as the shared values of a group or society; a process rather than a set of things - a set of practices. Primarily, culture is concerned with the production and the exchange of meanings - the 'giving and taking of meaning' - between the members of a society or a group. To say that two people belong to the same culture is to say that they interpret the world in roughly the same ways and can express themselves, their thoughts and feelings about the world, in ways that will be understood by each other.

When we later interpret the Afrikaans films against their historical backdrop, we will attempt to view them as cultural exchanges (in semiotic terms: a complex system of signs) that rely on an underlying cultural code to be understood. This cultural code gives a certain meaning to the films and meaning is what 'gives us a sense of our own identity, of who we are and with whom we "belong"' (Hall 1997:3). That said, culture is not a totalitarian concept and our (semiotic) approach does not preclude other possible interpretations or meanings.

The semiotic approach implies that senders and receivers share roughly the same cultural codes (in any process of communication) and that they should be able to read visual images in almost the same way; without this interpretative ability of receivers in the process of advertising, for example, the promotion of objects would fail dismally. Languages work through systems of representation and are in essence structures of communication or discourses in the words of Hall. 'Discourses', he remarks:

are ways of referring to our constructing knowledge about a particular topic or 'practice', these so-called discursive formations are ways to communicate about a certain topic and they define what is and is not appropriate in our formulation [...] The emphasis in the discursive approach is always on the historical specificity of a particular form or 'regime' of representation: not on 'language' as a general concern, but on specific languages or meanings, and how they are deployed at particular places. It points towards greater historical specificity the way representational practices operate in concrete historical situations, in actual practice. (Hall 1997:6)

In our analysis of two ostensibly 'simple' (but representative) ${ }^{3}$ Afrikaans films in the first decades of the 20th century, we adopt this definition of discourse. We do not provide 'correct' readings, but 'plausible' readings in terms of forms of signification. Our hypothesis is that meaning is constructed and that the language of film is, in terms of Lotman's definition, 'a secondary modelling system' (Lotman 1972:22). This implies that the receiver must know the code (of literature or film) in order to interpret the message (cf. Fokkema \& Kunne-Ibsch 1977:42).

It still remains to be seen whether the films under discussion can be termed 'realistic'.

Authentic literary realism provides the reader [spectator] with a discursive understanding of the socially conditioned acts of seeing [...] undertaken by the characters depicted. This affords the reader [spectator] a heightened consciousness of historical process and the act of representation [...] no novel [film] is realist because the author [director] seeks to render social experience visible by accounting for what was possible 3.These are only two films among many that try to impart an Afrikaner nationalistic ideology. 
to express and to observe within a particular social reality. (Barnaby 2008:43, our insertions, HC \& AvJ)

\section{The cultural (literary) system or field concept}

Cultural (and literary) systems are proposals for the classification of disparate cultural or literary material as interconnected wholes. It is, however, clear (according to Fokkema \& Kunne-Ibsch 1977:177) that diverse literary (cultural) systems differ. Schmidt (1992:215-216) distinguishes four operational roles (and for the sake of our argument, we use the terms cultural and literary as synonyms because of the fact that the literary field is a sub-category of the cultural field). They are literary production: any act of the production of a text and the aesthetic considerations involved, literary distribution: all acts that make a product available for other agents, literary reception: whereby meaning is ascribed to a product by agents in the field, and literary processing: all actions whereby a product is related to other products by summation, retelling, paraphrasing, evaluation or even analysing (cf. Barnard 1998:53, etc.).

Even-Zohar (1990:43-44) defines producers as groups or social communities engaged in the production of 'products' which can be 'an utterance, a text, an artefact, an edifice, an image or an event'. The production of these 'cultural items' is closely linked to what he calls reportorium, 'the aggregate of rules and materials which govern both the making and handling or production and consumption of any given product' (p. 39), the 'shared knowledge necessary for producing (and understanding) a "text"' (p. 40) which, of course, also refers to films. This view of Even-Zohar and that of Stuart Hall which we already discussed above show remarkable similarities and are indeed comparable to other literary terms.

Pierre Bourdieu is a French sociologist famous for his theory about the autonomous literary or cultural field with its own hierarchy and laws, which is closely related to systems theory. A cultural field is for Bourdieu a representative social space of cultural activity where different hierarchically arranged institutions, rules, rituals, conventions, categories, etc., produce (and legitimise) discourses and activities. In his terminology, a cultural field is a network of relations between groups and individuals that are in constant flux and in contestation for what he terms 'capital' and the distribution thereof.

One of Bourdieu's key terms is habitus, an institutionalised state, the way in which one regards oneself in relation to others, the set of internalised rules and conventions that rule our actions, our sense of decorum and even our norms, values and tastes. Many of Bourdieu's concepts were vehemently criticised, especially his concept of habitus that tends to describe culture as harmonious and homogeneous (cf. Verdaasdonk 1997:121; Sheffy 1997:38). It is also dubious whether the metaphor of contestation does justice to the dynamism within a literary field. As a hypothesis, it, however, contains certain valid assumptions, namely, that members of a cultural group share common values and 'codes', that within any literary field there is a cultural elite whose values and norms tend to dominate and can be directly linked, for example, to the process of canonisation, and that there is a competition within the cultural field for prestige and power.

Within this paradigm, it is also clear that literature and films, as products ('messages') of the cultural elite, will have a profound influence and will legitimise, for example, certain values and behaviour. Both Geboortegrond and Hans die skipper can be defined as products of the Afrikaner elite. Van Nierop (2016) devotes a whole chapter to the contribution of Pierre de Wet to the Afrikaans film. De Wet aspired in his numerous scripts and films to portray the Afrikaner as a sophisticated being and even experienced conflict with Joseph Albrecht, one of his major sponsors who regarded Afrikaners as mere diggers (p. 49). The fact that industrialists such as Albrecht were willing to sponsor De Wet is not only an illustration that Afrikaans films were a potential source of income but also illustrates the fact that De Wet was regarded as one of the Afrikaner elite. D.F. Malherbe is indeed a member of the Afrikaner elite of the first half of the 20th century: he was a direct ascendant of the founders of Die Genootskap van Regte Afrikaners (his father was one of the founding members, Gideon Malherbe). His promotion took place at the prestigious Fribourg University in Germany (where he obtained his PhD, summa cum laude). At a very young age, he was appointed as the first professor in the Department of Afrikaans, Dutch, French and German and was later appointed principal of the then university college of the Orange Free State that later became the University of the Free State.

\section{Representation in Geboortegrond (1946) and Hans die skipper (1952): Two case studies}

It seems to be evident that any study of, in this case, two representative Afrikaans films involves an interpretation or an evaluation based on a selective nationalism, because a large part of the South African film industry consisted of Afrikaans and Afrikaner films about white Afrikaner nationalism particularly during the period of Afrikaner emancipation. This period is a hypothesised period and historians differ as to a definite demarcation. Yet, it is usually coincided with the growth of the National Party (1924-34; 1948-1966) but 1934-1958 were the heydays of apartheid. There is currently a tremendous surge in the study of the South African film industry. Recent publications in this regard include Botha's overview, South African Cinema 1896-2010 (2012), Maingard's South African National Cinema (2007) and journal papers by Paleker on black films and ' $\mathrm{B}$ '-scheme cinema during apartheid (2010 and 2011), Tomaselli's The South African film industry (1979), The Cinema of Apartheid: Race and Class in 
South African film (1988) and Encountering modernity: twentieth century South African cinema (2006); Davis' In darkest Hollywood: Exploring the jungles of cinema's South Africa (1996); Botha and Van Aswegen's Images of South Africa: The rise of the alternative film (1992); Balseiro and Masilela's edited volume To Change Reels: Film and Culture in South Africa (2007) and Blignaut and Botha's edited volume Movies, Moguls, Mavericks: South African Cinema 1979-1991 (1992). In particular, very few studies of popular Afrikaans-language films have been undertaken, except for Le Roux and Fourie and Fourie's survey of white films made before 1980: Filmverlede: Geskiedenis van die SuidAfrikaanse speelfilm (1982), and Botha's descriptive overview of Jans Rautenbach's film oeuvre: Jans Rautenbach: Dromer, baanbreker en auteur (2006). It is evident that there is a significant gap in terms of the study of the Afrikaans film industry within the larger South African industry. Given that the Afrikaans film industry always had to positions itself in a very specific socio-political context that makes it a unique industry, it is necessary to describe its exclusivity in an attempt to see the possibilities with regard to its inclusivity.

By representing a specific ideological context as in typical Afrikaans films from the early 1920s up until the 1990s where aspects such as location, space and identity become important issues, the inevitable outcome, in most cases, is a description of an exclusive community and the emancipation of a colonised culture, as was previously mentioned in the case of Afrikaans films. A film industry that develops against such a socio-political background also runs the risk of being a manipulated industry. In the South African film industry, it was to be the case (cf. Botha 2007:51):

After the introduction of a regulated state subsidy scheme in 1956 for the South African film industry, up until the 1970s, the Nationalist government and big business collaborated to manipulate cinema in South Africa. Ideology and capital came together to create a national cinema that would reflect South Africa during the Verwoerdian regime, yet this started much earlier as a proactive initiative.

However, it was initially a cinema for white people only, and predominantly for speakers of Afrikaans. According to Davies (1989), the white Afrikaans audience for local cinema was relatively large and very stable, 'guaranteeing nearly every Afrikaans film a long enough run to break even as long as it provided light entertainment and dealt with Afrikaner reality and beliefs'. Examples of films from this era (the apartheid-era in South African filmmaking) include Die groot wit voël (1956), Die goddelose stad (1958), Ek sal opstaan (1959), Doodkry is min (1961) and Hans die rooinek (1961). The films that Botha refers to reflect a particular ideology underpinning South African filmmaking of the apartheid era. Botha omitted earlier films that clearly predicted ideas about apartheid or Afrikaner nationalism. However, this article deliberately focusses on two of these films and on the clear similarities in strategy when Afrikaner nationalism is depicted in them. Films in which Afrikaner nationalism is overt were already produced from the 1940s onwards. With the exceptions of filmmakers such as Manie van Rensburg and Jans Rautenbach, most of these films focussed on 'an attachment to the past, to ideals of linguistic and racial purity and to religious and moral norms' (Botha 2007:52). Several studies on South African films focus on the role of film in the establishment of a common identity and nationalism in different periods in the country's history: in the apartheid era, a white Afrikaner nationalism and after 1994, a different kind of black nationalism (cf. Botha 2012; Botha \& Van Aswegen 1992).

It essentially amounts to a specific representation of nationalistic cultural identity. This article takes into account the construction of ideology and identity by looking at how representation of the dominant culture locates itself in the socio-political landscape of the silver screen.

The next section of the article is an attempt to explain how Afrikaner nationalism is preached via representation, referring to Geboortegrond (1946) and Hans die skipper (1953). A critical reading of these cinematographic elements provides evidence of the historical context, discourses and values informing their production, as well as the construction and transformation of 'place' and identity in apartheid South Africa. The choice of these two films was determined by the specific dates of their first screenings and the fact that Van Nierop (2016:80) in his overview of the Afrikaans film linked these two films thematically as films where sons clash with hardy old fathers. It also adheres to another prominent thematic trait of the traditional Afrikaans plaasroman, that of the rebellious son leaving the farm (or fishing operations in Hans die skipper) as in one of the most seminal farm novels Laat vrugte (1939) by C.M. van den Heever. The films were released in the 1940s and 1950s, respectively. In this period, field marshal J.C. Smuts had an international reputation and was one of the founding members of the League of Nations (Die Volkebond). No one could envisage that only 3 years after the Second World War, Smuts, at the height of his power, would not only lose his constituency to a relatively unknown nationalistic candidate in 1948, but also that his party (the South African Party) would be defeated by the electorate. Yet, these years were important because of the consolidation of the Afrikaner and the boom of Afrikaner nationalism. This entire process of developing and sustaining Afrikaner nationalism is discussed in depth by two prominent Afrikaans academics, Lindie Koorts (2014) and Hermann Giliomee (2016). The National Party victory in 1948 was, in fact, the first step towards legalising apartheid, although the process of racial segregation has a long and complex history. An important feature of both these films is the absence of any profound portrayal of black characters. To some extent, both these films deal with the same themes:

- the generational conflict: especially between father and son, including the (obsolete) patriarchy;

- the importance of economic progress by embracing mechanised agriculture or alternative ways to earn money (the blacksmith's shop); 
- the pursuit of individual freedom which in concrete terms means to decide for yourself about your work, your time and especially your own earnings;

- the 'Conquest' or at least acceptance of the city or town by the Afrikaner. In this regard, economic 'conquest' is paramount;

- the importance of stable relationships, religion, idealism, values, etc., in this whole process;

- the farmer in the traditional (Afrikaans) farm novel as written in mythical terms in his heroic struggle against the powers of nature. In these films, this struggle is transferred to other spheres, for example, the sea.

Other classical Afrikaans themes of that time include issues on lineal consciousness (Coetzee 1985), the farm as an inalienable space and the farm as the place where the Afrikaner values not only still survive, but prosper.

Geboortegrond is a film by the South African filmmaker Pierre de Wet, with screenplay by De Wet himself and his sponsor, Joseph Albrecht, who could not even understand a word of Afrikaans. The script of this film with all the well-known themes from the Afrikaans farm novel makes an old-fashioned impression because of the fact that all these themes were already touched on by authors like C.M. van den Heever. In the aftermath of the influential Carnegie report on the situation of the so-called poor white people, C.M. van den Heever still attempted to convince his readers that an existence on the farm is much better than that in the city, the modern Sodom and Gomorrah. What is new, however, is De Wet's vision that the Afrikaner farmer will have to adapt to new and scientific methods of farming in order to survive. The implication is that the view on the Afrikaans farm novel at the time of the films' release, and still today, could be ascribed to a feeling of nostalgia, referring to an idealised farm that in reality did not at that time exist. The film reflects on the farm as space and the crippling effect that, among others, natural disasters had on the economic viability of the farm. Therefore, urbanisation had to be considered with all its associated evils and danger. This clearly is a reference to the Carnegie report (cf. Van Coller 2005:63).

Geboortegrond is the story of a typical patriarchal father who sets the rules for his family and is reluctant to change. He is the steadfast anchor in the community and provides for his people. His son Jan loves the farm but can no longer deal with the patriarchal construction that engulfs him. It is here that the influence of the producer and screenwriter, De Wet, is clearly visible. As a filmmaker he was influenced to a large degree by Isadore Schlesinger who provided the capital to make Afrikaans films from as early as the 1930s. For this, he was constantly reproached by his people because he would presumably receive money from foreign investors for making Afrikaans films and was denounced as a traitor (Van Nierop 2016:49). In Geboortegrond, one finds a change of focus towards a deeper economic awareness among the younger generation and a rebellion against the cultural past. Dr D.F. Malan (Prime Minister of South Africa from 1948 to 1954) was initially vehemently opposed to the city, yet changed his attitude in 1938, proclaiming that the Afrikaner should 'conquer' the city (Van Coller 2005:65). As in Hans die skipper, the son is still regarded as being under the thumb of his father, but the focus now shifts to development and progress. Money makes you independent while drinking and gambling, the great sins of the city, still foreground the dangers of the city. However, a cultural repertoire and specific knowledge of the Afrikaans novels on farm and city will give the viewer insight into the discourse of the specific time, along with the interpretation of the above context.

The birth of Jan's own son rekindles his love for the soil and he returns to make a living as his father did, but now in a far more developed and mechanised way. His farming practices are now more modernised for the sake of his own son's future on the farm. This film deals with the clash of generations, especially because of mechanisation; the new generation who see the city or town as a place to 'conquer' in terms of the dictum: 'Pay the worker the wages he earned', and the implication that although hard work is needed, it is not the be-all and end-all of everything. There should also be room for relaxation and pleasure. Despite the rise of this new generation, however, elements of cultural heritage still occur. For example, on a cinematographic level, the consistent focus on the row of trees, especially at the entrance to the farm, by implementing wide angled camera shots, almost pulls the viewer into the past. These trees represent the ancestors who have cultivated and tamed the farm. It becomes an implicit ode to tradition. It is therefore no coincidence that cemeteries are always close to the tall trees, given that the graves symbolise the generations joining present and future. With the necessary awareness of the cultural repertoire of the Afrikaner, the sophisticated viewer would be able to grasp these references. This interpretation is almost forced upon the viewer in that the opening sequence focusses pertinently on outdated, traditional farming methods such as the use of oxen pulling ploughs. Later, in the closing scene, cultural continuity is further stressed in the scene with the farmer carrying his grandchild on his shoulders towards the maize crops - implying an inherited but also a new feature that is cinematographically suggested rather that explicitly depicted.

The Afrikaans film, Hans die skipper (1952), by director and screenwriter Bladon Peake, was produced in 1952 as a re-writing of the eponymous novel by D.F. Malherbe, published in 1929. Both these films speak clearly to the Afrikaner-volks-ideal, socio-political change, race and labour relations, patriarchal identity as well as religion and family. Because of the fact that Geboortegrond and Hans die skipper's film versions were released in the 1940s and 1950s, a time when Afrikaner nationalism (as said earlier) peaked (after the Second World War and after the National Party victory), both imply to a great extent the following message: 
accept the city, work hard and succeed, embrace modernisation, but at all times be true to your principles of honesty, loyalty, tradition and the like. ${ }^{4}$

In 1940, the Reddingsdaadbond-Amateur Film Organisation (RARO - part of the economic mobilisation of the Afrikaner in the 1940s and 1950s) was founded. It was a direct result of the first Volkskongres in 1939 with the aim of economic empowerment of the Afrikaner. Dr Hans Rompel would play a major role in this process (Van Nierop 2016:36) and in the words of Tomaselli (2006), he said: '...the ideal Volksfilm (People's film) should propagate the idea ... of an uncontaminated and pure Afrikaner society'. These People's films had a specific intent, and that was the cultural upliftment and representation of the 'true Afrikaner'. The message of these films is conveyed to the viewer in a multi-layered manner: a symbolic landscape together with educational and didactic dialogue become important forms of ideological, economic and cultural manipulation. It is the underlying hypothesis of the article that even seemingly simple images portraying the Afrikaner within their cultural frame of reference cannot be successfully interpreted by the viewer unless he or she shares the repertoire that is ostensibly referred to by both films. Though Geboortegrond falls clearly within the sub-genre of the traditional Afrikaans farm novel, Hans die skipper in actual fact also falls within this sub-genre. One can replace 'sea' with 'farm' and all the important themes are still present: the demise of a way of life, lineal consciousness and the changes in the hierarchy between the mother and the father as well as the end of a patriarchy and the patriarchal dynasty.

Most of the scenes in the films confirm the fact that the Afrikaner has a historical and political claim on the South African landscape and has almost been inscribed into it. Hans die skipper tells the story of Hans, the captain of a fishing boat in a fishing village in the 1920s. His dream is that his only son Johan will follow in his footsteps. He regards himself as the skipper in the community and not a mere fisherman like all the other men in the village. He buys his son a boat so that he can follow in his father's footsteps but Johan leaves the village to fulfil his dream of a better future in the town or city. Devastated, Hans falls ill, reconciling with his son only on his deathbed. This closing scene (the epiphany) is ironic: the delusional Hans thinks that his son is returning to continue his father's calling, but in actual fact, Johan returns not only to bid farewell to his dying father but also to take his mother with him to go and live with him in town, in a more developed environment.

Both films symbolise the Afrikaner Nationalist idea where children should not doubt their father's wishes, where tradition and family heritage are paramount. Landscape analyses tend to focus exclusively on landscape representation. However, in recent years, visual representation-focussed,

4.In 1933 Dr Malan challenged British imperialism's ascendency over Afrikaner nationalism. In 1938, Dr Malan, who initially decried urbanisation, argued that it nationalism. In 1938, Dr Malan, who initially decried urbanisation, argued that it
was given, and his plea for a vanquishing of the city became a subsequent refrain was given, and his plea for a vanquishing of the city became a subse
(Van Coller 2005:65) (see also Koorts 2014:71, 227, 269, 281, 288). historical and interdisciplinary studies of South African landscape and culture have emerged, including Foster's Washed with sun: Landscape and the making of white South Africa (2008) and Beningfield's The frightened land: Land, landscape and politics in South Africa in the twentieth century (2006), Coetzee's White writing: On the culture of letters in South Africa (1988) and Van der Merwe's edited volume Strangely familiar: South African narratives in town and countryside (2001) (Riley 2012:14). They observe themes and tropes that can be effectively put into practice beyond literature to film and other visual media.

The landscape in both films is depicted as harsh and unrelenting. In Hans die skipper, Hans constantly emphasises the fact that, in his own words: 'Life at sea is no easy task'. ${ }^{5}$ He himself lives in a small humble dwelling like all the other workers in the village. Hans lives close to the sea which implies that he regards the sea as his master and is humbled by the force of the sea and acknowledges his inferiority and dependence on this master of his. He says: 'No fish will emerge from a rock pool unless the tide brings them in' and 'the sea makes our chimneys smoke'. ${ }^{6}$ When there is talk of the sea in Hans die skipper or of land in Geboortegrond, as spatial orientations, it invokes specific connotations within the South African reality. In a broader African context, man versus space equals vastness. These spaces, namely, sea and land within the borders of South Africa, become strong forces that affect the individual. Among other things, it shows the individual's dependence on and submission to the land for his survival. This dependence on nature also comes to the fore in Geboortegrond, in the constant wide angle camera shots of the farm and the fields throughout the film. It creates the illusion of the vastness of the farm land, seeing that land to the farmer is equivalent to security and status. The more land he owns, the stronger and more successful and blessed the farmer is. The manipulation of space through these shots of successful farming practices places the emphasis in Geboortegrond on land or place as a historical and political instrument in the hands of the Afrikaner through which he can demonstrate his identity and status as a successful farmer and provider. The first 4 min of Geboortegrond, which is in total only $64 \mathrm{~min}$ long, are largely taken up by visuals of the white farmer and his son ploughing his own lands using traditional methods, gathering seeds, milking cows and wide angled shots of farmlands with hardly any dialogue. This presentation of space or landscape significantly demonstrates the importance of land, the farm, production and the attainment of economic independence that were all very important within the context of Afrikaner nationalism especially in and around the 1930s. In the background, the viewer can hear the well-known song, 'O Boereplaas' that was made famous by the renowned soprano, Mimi Coertse. The words by C.F. Visser were set to music by Johannes Joubert. The lyrics speak about a deep love for land and country:

5.'Die lewe op die see is nie maklik nie'.

6.'Geen vis sal uit hierdie poel uitkom tensy ' $n$ brander hom nie uitspoel nie'. 'Die see laat ons skoorstene rook'. 
O, BOEREPLAAS

O boereplaas, geboortegrond!

Al dwaal ek heel die wêreld rond, waar so gelukkig, so gesond?

O boereplaas, geboortegrond! Jou het ek lief bo alles.

O moederhuis, waar ooit so tuis?

Jou het ek lief bo alles.

Die wêreld, rykdom, prag en praal

kan jou verlies my nooit betaal.

O moederhuis, waar ooit so tuis?

Jou het ek lief bo alles.

O moedertaal,

o soetste taal!

Jou het ek lief bo alles.

Van al die tale wat

ek hoor,

niks wat my siel ooit so

bekoor.

O moedertaal,

o soetste taal!

Jou het ek lief bo alles.
Jou het ek lief bo alles.

O AFRIKANER FARM ${ }^{7}$

O Afrikaner farm, o place of birth

You I dearly love; you give me mirth

Even if through the world I

roam,

here I am happy and call it home.

O Afrikaner farm, o place of birth

You I dearly love, you give me mirth.

O never happier than at my mother's hearth

You I dearly love, you give me mirth.

The world, wealth, pomp

and splendour

will never be for your loss a contender.

O never happier than at my mother's hearth

You I dearly love, you give me mirth.

O mother tongue, sweet speak of birth

You I dearly love, you give me mirth.

$\mathrm{O}$ all the many languages

that I know

None that on me that much pleasure bestow

O mother tongue, sweet

speak of birth

You I dearly love, you give me mirth.

In Hans die skipper, the camera deliberately jumps from wide angled shots of the sea to shots of the adjacent fishing village with the song 'Vêr in die Wêreld Kietie', linking them as a strong unit to indicate Johan's desperate need for a better life over the one in the fishing village which he later finds on the other side of the mountain in the nearby town. He describes himself and his unhappy state in the village to his girlfriend in terms of a fish caught in a rock pool. He says: 'I feel like a trapped fish in a rock pool. Hopefully the storm will one day throw me out on land'. ${ }^{8}$ This citation also illustrates the different perspectives of father and son pertaining to life at sea as, on the one hand, the provider of life as seen by the father and, on the other hand, as the sea as a form of entrapment as seen by the son. Johan's dialogue is a direct reference to his father's words: 'No fish will emerge from a rock pool unless the tide brings 7.Authors' own translation.

8.'Ek voel soos ' $n$ vis wat vasgevang is in ' $n$ rotspoel. Hopelik sal ' $n$ storm my eendag op die land uitgooi'.

them in'. ${ }^{9}$ Both these statements make use of the fish image (as metaphor) as well as the image of the rock pool. Where the father implies that only an intervention will make fish accumulate in the pool, the son by contrast yearns for the same intervention to free himself from the pool. The words of the song resonate in Johan's words of desperation:

VÊR IN DIE WÊRELD

KIETIE

Vêr in die wêreld Kietie,

Kietie, Kietie

Vêr in die wêreld Kietie,

Kietie oor die see

Sy laat haar draai, sy laat

haar swaai

Maar sy laat haar nie verraai.

Sy laat haar draai, sy laat

haar swaai

Maar sy laat haar nie verraai.

FAR IN THE WORLD

\section{DEAR KITTIE ${ }^{10}$}

Far in the world dear Kittie, Kittie, Kittie

Far in the world dear Kittie, Kittie overseas.

She'll let you swing her, she'll let you sway her but will never allow you to betray her.

She'll let you swing her, she'll let you sway her but will never allow you to betray her.

When Hans buys Johan his own boat, Johan's name is engraved on the side of the boat. This becomes a further indication that even tangible items are engulfed in the space they occupy. The boats become the people they represent and when the boats are visible in the last scene in the film, weathered and desolate, they represent a passing generation as well as the old and the previous gone by.

Seeing that Hans die skipper attempts to draw on his audience's experience of the changing world, Afrikaans-speaking white South Africans confronted with a rapidly changing society that coheres with the loss of cultural identity as well as financial stability, the setting is in a style that underscores their ideological position at the time of the film's release but also in retrospect with regard to resent interpretations. It celebrates the rural order where everything on the village's side of the mountain is good and the mountain itself becomes a border that has to be crossed physically and ideologically (cf. Debray in Nairn 2013). In metaphorical and liminal terms (Van Gennep 1996:529), it is the threshold that has to be crossed. Cinematographically, this is established by never allowing the viewer to see the world across the mountain range. In the film, the town or city is never portrayed visually. It is an off-screen space that has an important meaning, and is therefore deliberately left for the viewer to visualise internally. This is a space which the young Johan yearns for. It is something new and becomes a symbol of progress and deliverance from whatever limits him in the fishing village. By not portraying it visually, the viewer is given the freedom to interpret the context within his or her own frame of mind, broadening the contextualisation thereof.

On the other hand, the fact that Johan never returns to follow in his father's footsteps shows that Hans's era is long gone and a new generation has arrived. It is eventually suggested that, while ideology is important, so is change.

9.'Geen vis sal uit hierdie poel uitkom tensy ' $\mathrm{n}$ brander hom nie uitspoel nie'.

10.Authors' own translation. 
In Geboortegrond, a different technique is used to establish the underlying conflict between farm and city. Scenes from the farm and scenes from the city are shown in quick succession to visually demonstrate the conflict between the two spaces but also to demonstrate the opposing ways in which the characters relate to landscape. In the city, the camera only focusses on Jan's feet and his worn shoes that tread on hard concrete pavements (Van Nierop 2016:51). By contrast, the camera focusses on the scenes on the farm in such a way that the farmer not only merges with the space but also because of the camera angle, becomes almost larger than life. De Wet hereby renews the traditional view of the city and progress in the traditional Afrikaans farm novel by juxtaposing a deteriorating farm with Jan's prowess in selling modernising farm equipment in the city.

Neither film is a neutral representation of Afrikaner rural life as it was, but, in actual fact, the glorification of labour where the worker becomes the hero who overcomes all obstacles to the fulfilment of his idealised dream - a topos in nationaldocialism. This can clearly be linked to what Amuta and Ashcroft termed aggressive nationalism (Ashcroft et al. 1989:33). The viewer ostensibly grasps this interpretation spontaneously. Yet, in actual fact, it depends on grasping two repertoires simultaneously: that of cinematographic elements (such as a montage of images, numerous still images and image sequences together with sequential dialogue), as well as the ideological ones which have already been explicated and largely depend on knowledge of the traditional Afrikaans farm novel.

Hans die skipper, produced by Schlesinger's African film productions, shows that even in an English-produced and directed film, Afrikaner nationalism of the late 1920s was depicted. In the 1920s-1940s, the Afrikaner was in dire economic straits due in large part to the loss of farmlands that resulted in large-scale urbanisation of poor Afrikaners, who were forced to move to the city and to compete with increasing numbers of black labourers in the industries in previously largely 'English' cities. At that time, Afrikaner nationalism was utilised as a meaningful construct to at least instil a sense of pride.

In Hans die skipper aversion to the city and the effect thereof on the Afrikaner (cf. Van Coller 2005) is foregrounded. Memories of what used to be are played out in a very long opening scene that compels the viewer to realise the importance of a so-called Afrikaner tradition - that of traditional ancestor pride but also a strong religious aptness and awareness of God's presence. Flashbacks are done in a one-dimensional narrated fashion when the schoolmaster recalls how it used to be when Hans was still a strong successful skipper. Montage images are stacked one on top of the other to enhance the importance of the prominent father figure, Hans. By means of auditory clips in the voice of Hans himself, the viewer is reminded of an almost naive believe in a God that demands obedience and, in turn, will provide. In the words of Hans: 'I am always thankful because the sea (and by implication, God) is always good for me', 'The Lord will show the way. He will provide', 'If I do well by God, I will see the fruit of my work'. ${ }^{11}$ At the end of the film, the schoolmaster talks to the dying Hans in the typical idiom of the time and the place when he says:

There is a steersman on every boat and He takes us where $\mathrm{He}$ decides, sometimes on flat seas, sometimes in the storm, but each and every boat will return to land... ${ }^{12}$

implicating that Hans's and Johan's boat will eventually return. When Johan indicates that he wants to leave, Hans tries to lure him back through emotional manipulation, saying that he could never leave because of the 'love for the sea that will always burn within him'. ${ }^{13}$

Opposed to the image of the patriarch, Johan turns his back on the village and seeks his future in the town (p. 194 in the 1929 novel): 'In the nearest town he lived from hand to mouth for a week, and then good advice and a favourable travel opportunity brought him here to the wagon factory' ${ }^{14}$ Then follows a description of the 'here and now':

It was spring in the oak bloom and in the fruit gardens, spring on cornfields and the singing of birds, spring in budding green fields, and in Johan's heart was the spring of work urge and expectation. $^{15}$

The description is reminiscent of a place like Caledon or Ceres. It implies the birth of the new, the youth, against the dying of the old, the father. It also refers to the new economic future.

In Hans die skipper, Johan's work in the forge is almost described in almost mythical terms. On page 188 in the novel, we find the following expressionistic description, a written counterpart of massive artworks typical of the social realism or Marxism where heroic labour is commemorated. These kinds of Marxist ideals are also overtly present within the nationalist ideology. One only has to look at the example of the 1922 mining strikes to see this to be true.

Wild sounds of hammers on anvil, massive hammer steel on glowing white iron, on end, with the severity of power shots that releases spark splashes through the shadows of the forge like meteor showers - bright and dull, bright and dull, hammer music that overpowers the welding with dirt, ash powdered braggarts monstrously bending over the fireplace, secure-calculated shots falling from high where shining gripping arms wrestles with soaring steel weight! And through the staggering sparks raining down and

11.'Ek is altyd dankbaar want die see is altyd goed vir my. Die Here sal die weg aanwys. Hy sal sorg. As ek God se wil doen, sal ek die vrug op my arbeid sien'.

12.'Daar is 'n stuurman by elke skuit en Hy voer ons waar Hy wil, somtyds op gladde plesierige see, somtyds in die storm in, want elkeen se skuit kom terug land toe'.

13.'Die liefde vir die see wat altyd in hom brand'.

14.'In die naaste dorp het hy 'n week lank van hand tot mond gelewe, en daarna het goeie raad en ' $n$ gunstige reis-geleentheid hom hier na die wafabriek toe gebring'

15.'Dit was lente in eikebloei en vrugettuine, lente op graanlande en in die gesang van voëls, lente in die spruitende groen van die veld, en in Johan se hart was die lente van werkdrang en verwagting'. 
massive hammering, the clash of force with force, and under lasting wrestling with stubborn matter forward and backward as the chimneys show, commanding voices occasionally breaks lose, challenging voices and mock voices from diligent men. ${ }^{16}$

To an extent, Johan is reminiscent of the mythical figure Hephaestus, the smith in Greek mythology who made wonderful artworks despite his paralysis. He is the son of the supreme god Zeus who chased him away. In Malherbe's novel, Johan is also 'chased away' by his father.

The lyrical descriptions of labour in the forge (sited above) are almost comparable to the lyrical descriptions of Hans's work at sea. See, for example, the descriptions:

And it did not last long before the sails began to bulge so that the wind could straighten out every wrinkle therein, and the front mast begins to gallop on broader swells like a horse's limbs that loosen as he picked up speed. ${ }^{17}$ (p. 151)

Through this image, the implicit author suggests that one should do one's job with joy and enthusiasm and that there is no hierarchical difference in the things you undertake. This in itself is comparable to the Marxist ideal of the (working) proletariat. One of the most important descriptions in the novel is on page 194:

On a Saturday afternoon after receiving his first salary he [Johan] self-consciously with own earned money in the pocket with his hand carefully clinging onto it - pound notes and halfcrowns - walked up the street to buy the necessary pieces of clothing. He always had a great respect for a heavy, shiny halfcrown piece! It was money you had to tip your hat to! And he never had the privilege to hold it in his hand, and know that it was his own, which he can do with whatever he liked without anyone to account for. How the joy of owning moved him! Then he felt the legal money. Pound notes and heavy pieces of silver ... his, his, his! He felt it safely stored in the hollow of his hand and he felt the fierce pride in his cheeks and he thought of Nelie, what she would say. ${ }^{18}$

The silver coins that become increasingly important to Johan while in the town and drives him and his father further and further apart and with which he in actual fact betrays his father, can easily remind the viewer of Judas who betrayed

16. Wilde geklink van hammers op aambeelde, van massiewe hammerstaal op gloeiwit yster, aaneen, met die hewigheid van kraghoue dat vonkspatsels verbyflits deu die halfdonker van die smidslokal soos sterrereën - helder en dof helder en die halfdonker van die smidslokaal soos sterrereen - ho hammermusiek wat die sulswerk blaasbalke, monsterlywig oor die vuurherde geleun, sekuur-berekende houe wat val uit die hoogte waar ligtende vasvat-arms stoeir verbysterende vonkereën en sidderende beuking van krag met krag, en onde durende gestoei met hardnekkige materie vorentoe en agtertoe soos die skoorstene wys, breek af en toe bevelstemme los, uitdaagstemme en spotstemme van arbeidslustige manne!'.

17.'En dit het ook nie lank geduur nie of die seile begin al meer uitstaan dat die wind elke plooi daarin glad stryk, en die voorste begin kopspeel oor breër deinings soos n perd wat die litte van los word as hy vaart kry'.

18.'Op 'n Saterdagmiddag na ontvangs van sy eerste loon het hy selfbewus met eie, verdiende geld in die broeksak waar sy hand dit sorgvuldig vasklou - pondnote en halfkrone - die straat opgestap om die nodigste stukkies klere te koop. Hy het altyd so'n groot respek gehad vir' $n$ swaar, blink halfkroonstuk! Dit was geld om jou hoed voor af te haal! En nooit het hy die voorreg gehad om dit in sy hand te hou en te weet dat dit sy eie is nie, wat hy mee kan maak soos hy wil sonder om iemand daarvan rekenskap te gee. Hoe het die vreugde van besit hom ontroer! Daar voe hy die wetlike geld, pondnote en swaar silwerstukke ... syne, syne, syne! Hy voel dit veilig gebêre in die holte van sy hand en hy voel die gloed van trots in sy wange en hy dink aan Nelie, aan wat sy sou sê'.
Jesus for 30 silver coins. Money is as important to Johan as the boat is to Hans. It is, on the other hand, in Geboortegrond, as important to Jan as the land is to his father. In both films, the representatives of the older generation stand in stark contrast to the younger generation as represented by their two respective sons: financial independence by earning one's own money is seen as lofty an ideal as toiling away on land or on the sea.

The strongest scene in the film that underlines the overwhelming claim that the landscape has over the characters is the one in which Johan's mother reads a letter from him out loud to his father. The father responds:

He works in a blacksmith's shop? Where he inhales coal fumes until it sticks in his nostrils and his lungs. The bright, blue sea, the most beautiful that God has created, he doesn't want to see. The darkest of the waves, he doesn't want to hear. But ashes, he wants to eat in a blacksmith's shop. That is sacrilege, my beloved wife. ${ }^{19}$

This denigrating description stands in stark opposition to the one quoted later, depicting the focus of Johan. The vision of Hans is stigmatised by the implicit author when Johan returns to his father on his deathbed dressed in a black suit. He appeared as a mirror image of the schoolmaster, opposed to the image of his father in an old jersey over a shirt. It is ultimately a symbol of his acceptance of progress and innovation.

Both these films represent the challenges to Afrikaner identity, the destruction of the religious Afrikaner patriarch, as well as the Afrikaner family values and their way of life. They are loaded with opinions on core aspects of Afrikaner nationalism and the discourse aims to provide clear answers on the essence of Afrikaner nationalism at the time. It portrays the characters as strong archetypes in allegorical terms: in Hans die skipper, Johan is the rebel against his destiny and stands for the contemporary Afrikaner ready to embrace the future in the city or town, whereas Hans represents the outdated heroic struggle against nature. The demise of this old order (and of the patriarchy) is metaphorically depicted at the end of the film in the wreckage of Hans's boat.

In Geboortegrond, the farm is the place where Jan, the son, feels safe. The farm becomes an extension of the family, built by the patriarch and his forefathers. Outside the confines of the farm, the son feels out of place. People laugh at him at communion because of the way he is dressed. This portrayal of Jan leads the way for the viewer's experience of the anticipated loss of cultural identity that came with urbanisation.

In his quest to uphold the standard of living of his family on the farm, the father runs the risk of losing touch, not only

19.Maar gebukkend wil hy liewer staan by die vullishoop van'n smidswinkel. ' $n$ Slaa wil hy wees wat steenkooldampe inasem tot dit in sy neusgate sit en in sy longe. Die blink blou see, die mooiste wat God geskape het wil hy nie sien nie. Die donker stem van die branders wil hy nie hoor nie, maar as wil hy vreet in ' $n$ smidswinkel. stem van die branders
Dis heiligskennis vrou'. 
with reality, but also with his son. His son blames him for wanting to keep him back with the words:

You like it that I am dependent on you. You buy my clothes. You tell me what I should do, how I should work. Everything I do must be the way you want it. ${ }^{20}$

When he then announces that he is leaving the farm for the city, his mother tries to stop him with the words:

Don't talk to your father like that. You can't go away. Your place is here on the farm with us and your father knows what is best... You grew up on the farm and it is all you know. ${ }^{21}$

Jan answers with:

No father, you don't know what is best...Father, you think that those few acres are heaven. You think that I never want to do anything else but work for you, but I am sick of it. ${ }^{22}$

Ironically, what triggered him leaving the farm also prompted his return to the farm. In the beginning of the film, at communion, the other young people laughed at him and made fun of him because of the way he was dressed. Towards the end of the film, at a work function, he was again laughed at, which was the last straw leading to his decision to return to the farm. Eventually, Jan realised that he was, in fact, the farmer that his wife Bettie knew he was all along. The circle is completed and the heritage restored.

The cultural processing that pre-empts understanding of a cultural text involves elements of editing, mise-en-scene, but also Even-Zohar's 'cultural items' such as an utterance, a text, an artefact, an 'image' or an 'event'. This implies, as previously stated, a 'shared knowledge ... for producing and understanding a text' (Even-Zohar 1990:43-44). To understand and interpret Geboortegrond and Hans die skipper within the boundaries of their contexts, the viewer needs to be familiar with the habitus, to understand the socio-political background of the era, know the symbolic value of the artefacts from the specific time and understand the psyche of the Afrikaner of the time. The viewer should therefore constantly be reminded of the overall objective of these films; that of exploring and signifying the patriarchal nature of Afrikaner culture together with the Christian Nationalist ideal. Van Coller (2006:93) emphasises this particular state of mind by stating that the Afrikaner has always, and still holds a somewhat ambivalent stance towards the city and, in actual fact, has never completely been at peace with it.

Considering the earlier warning of Edward Said on the reader's understanding of a humanistic text by living the author's reality, the viewer is confronted by a representation of the conflict between rural and urban life and its moral

20.'Pa hou daarvan dat ek van Pa afhanklik moet wees. Pa koop vir my klere. Pa sê hoe ek moet werk. Alles wat ek doen moet wees soos Pa dit wil hê'.

21.Jan, moenie met jou pa so praat nie. Jy kan nie weggaan nie. Jou plek is hier op die plaas, by ons, en jou pa weet wat die beste is ... Jy't grootgeword op die plaas en dis al wat jy ken'.

22.'Nee Ma, Pa weet nie wat die beste is nie ... Pa dink daardie mislike paar morge is die hemel en dat ek niks anders in my lewe sal wil doen as om daar te bly en te werk soos 'n esel nie, maar ek is siek en sat daarvan'. and economic implications through the use of audio and visual presentations. The films basically force the viewer to assimilate the characters' visions. It becomes evident to the viewer that the inherited behaviour of the characters, learned through association and dealing with culture, can hardly ever be denied. An untainted historical view is visible, but in both these films, it does not merely stagnate as a stereotypical description. Rather, it evolves into a more relativistic and even positive vision of urbanisation and mechanisation. In Hans die skipper, for instance, Hans's and the schoolmaster's clothing depicts their social status. This is visible in the opening scene. Even the conversation between them indicates that the schoolmaster is the superior one when it comes to thinking. In economic terms, the schoolmaster represents education and mobility. Hans's thoughts and ideas, on the other hand, are more basic and traditional by comparison. The visuals follow the evolution towards urbanisation and mechanisation in the way the characters dress. In the beginning, Hans and his son Johan look almost identical. They wear old clothes, tattered trousers, old jerseys and an old worn hat and a woven cap. The more Johan becomes aware of the possibilities in the nearby town, the more the viewer sees him change in terms of his attire. In the scene where he shares his real feelings about the sea with his father, he is already alienating himself visually by wearing a blazer instead of an old jersey over a shirt. In the final scene where he returns from the town to his father's deathbed, he stands next to the schoolmaster in juxtaposition to the image of his father as a mirror image of the schoolmaster. The latter's influence on Johan, and therefore the influence of modernisation and urbanisation on his character, are also represented in verbal utterances. In a letter to his parents, he writes: 'The schoolmaster always said, whatever you do, do it well. And I am trying to do that mother'.23

In Geboortegrond, the so-called habitus comes to the fore in a different and somewhat ironic way. Bettie, the wife of Jan, was brought up on a farm. She therefore verbalises that she would like to marry a farmer. She expresses her love for Jan in terms of his strengths and knowledge as a farmer, born and bred, and whose heart knows nothing else than an overwhelming love for the land. This worshiping of the farmer as patriarch also touches on the concept of the woman as a 'Serving Martha' within the patriarchal system. Bettie even goes to the farm when Jan's mother falls ill, to help with the household. She who fled from the farm for a better life in the city, then ironically saves Jan and herself from the city when he is overcome by wealth and drinking, by making him go back to the farm. There they will bring up their son where they all belong, even though with more experience of modernisation and mechanisation in hand. These presentations strongly correlate with Van Coller's (2006:92) views on this matter when he states that in these types of novels, many of the memories of the characters are nostalgic in nature.

23.'Ek onthou wat Meester altyd gesê het: wat jy ookal aanpak, doen dit goed. Ek probeer om daardie woorde na te kom, Moeder'. 
The dialogue in Hans die skipper serves as a constant reminder of the importance of family values and tradition, in the words of Hans: 'What my father taught me, Johan will learn from me' and on his deathbed, 'Johan will always be my hope and my desire' ${ }^{24}$ There is an ongoing verbalisation of holding on to the past and carrying it into a future. When asked about how he foresees his son's future, he profoundly utters: 'What was good (working as a fisherman) for my grandfather, my father and for me, will be good enough for Johan too' ${ }^{25}$

The events leading up to the death of the main character in Hans die skipper slowly introduce the viewer to the inevitable. Samuel, his former right hand, indicates that he wants to retire. Immediately thereafter, Willem, his current right hand, announces his retirement. In an emotional scene, Johan then says his farewell after he expresses how he hates the sea and the life that his father planned for him. After the departure of his only son, Willem leaves and Samuel dies. The sequence of these events shows the crippling effects of not only the death of the patriarch, but, in a metaphorical way, also the effect of modernisation.

Bourdieu's view on the members of a cultural group who share common values and 'codes', together with Hall's semiotic approach to signs in texts, lays the foundation for a specific interpretation of the artefacts in both these films. In the scene in Hans die skipper where Johan tells his father that he is leaving the village for the city or town, the mise-en-scene is well thought out when the viewer is confronted with, in the background, a photo of his grandfather. In an image where the present is dominant over the past, it is visually enhanced with the past deliberately silent in the background.

The kierie or walking stick that Hans receives from his grandfather is a significant artefact in the film. It is important that the viewer realises that it was a gift that was passed from generation to generation. It becomes a baton of continuity. After Johan's departure, Hans is left with no reason to live and the image of him and his kierie shows a lonely man with nothing but a wooden stick, that was once symbol of family values and a prosperous future. It is fitting that he then gives it to the schoolmaster because it no longer has any significance to him. In these two films, cultural memory is loaded with meaning, especially in inherited objects (such as family photos and the walking stick), that connect the characters with something bigger than themselves. It gives them identity and value within a cultural realm. Their connection with these artefacts makes them part of a larger cultural community and empowers them as part of a whole. This also empowers the viewer who recognises these values and 'codes' in their process of decoding and interpreting the visual images.

In Geboortegrond camera angles are effectively used to show the transition in terms of identity and cultural structure

24.'Wat my vader van sy vader geleer het, en ek weer van hom, moet Johan nou van my leer. Johan sal altyd my hoop en my verwagting bly'.

25.'Die see was goed genoeg vir my pa en vir my oupa. Dis goed genoeg vir my en dit sal goed genoeg vir Johan ook wees' within the Afrikaner community. When Jan confronts his father about the outdated patriarchal system that he has to adhere to, the viewer sees the father sitting in a visually inferior position and Jan standing in a visually superior position in relation to him. Even without dialogue, the viewer is manipulated through special oppositions to interpret the scene in a specific way. Jan's mother hands him a ring on his departure so that he can sell it in order to survive. The ring, which is, in fact, an heirloom, is later returned by his wife to the ailing mother. This reciprocates the eventual return to the farm and in essence symbolises lineal consciousness (cf. Coetzee 1985). Eventually, the farm also metaphorically returns to the Afrikaner with the image in the eye of the viewer of Jan's father carrying his grandson on his shoulders towards the ploughed fields that will probably one day become his.

The study of film is primarily a study of cinematographic language that represents objects of visual culture to examine the interaction of word and image. This implies an examination of cultural identity formation and landscape representation. 'An integrated "visual literacy" methodology is therefore important because it is based on a familiarity with the discourses and conventions (or "tools") of both film and landscape representation' (Rosenstone 1995:16). Meaning is established through an understanding of the abovementioned contemporary symbols, signs and 'historically specific intertextuality' (Panofsky 1957:144 in Rose 2007). The basis of the analysis of cultural forms such as those produced in service of Afrikaner nationalism, constructed in various media, including literature (the farm novel) and film, lies in representation, as it is shaped in a specific world at a specific time. It reveals evidence about history and the role history has to play in constructing new worlds. The complexity of interpretation makes it an ongoing dynamic process.

\section{Acknowledgements Competing interests}

The authors declare that they have no financial or personal relationships that may have inappropriately influenced them in writing this article.

\section{Authors' contributions}

H.v.C. was responsible for the initial structuring of the theoretical section but with contribution from A.v.J. and she was also responsible for the initial structuring of the conceptualisation with contribution from H.v.C.

\section{References}

Amuta, C., 1989, The theory of African literature, Zed Books, London.

Andringa, E., 2006, 'Penetrating the Dutch Polysystem: The Reception of Virginia Woolf, 1920-2000', Poetics Today 27(3), 501-568. https://doi.org/10.1215/0333 5372-2006-001

Ankersmit, F.R., 1986, Denken over geschiedenis. Een overzicht van moderne geschiedfilosofische opvattingen, Wolters-Noordhoff, Groningen.

Ashcroft, B., 1989, The empire writes back, Routledge, London.

Auerbach, E., 2013, Mimesis. The representation of reality in Western literature. With a new introduction by Edward Said, Fiftieth Anniversary edn., Princeton University Press, Princeton, NJ. 
Balseiro, I. \& Masilela, N., 2007, To change reels: Film and film culture in South Africa, Wayne State University Press, Detroit.

Barnaby, E., 2008, 'The realist novel as meta-spectacle', Journal of Narrative Theory 38(1), 37-59. https://doi.org/10.1353/jnt.0.0004

Barnard, R., 1998, 'Kanoniseringsprosesse in die Afrikaanse literatuursisteem: Die ro van N.P. van Wyk Louw', Ongepubliseerde PhD-proefskrif, Universiteit van die Oranje-Vrystaat, Bloemfontein.

Bar-Yam, Y., 1997, Dynamics of complex systems, Westview Press, CO.

Blignaut, J. \& Botha, M.P., 1992, Movies, moguls \& mavericks: South African cinema 1979-1991, Showdata, Cape Town.

Botha, M.P., 2006, Jans Rautenbach: Dromer, baanbreker en auteur, Genugtig! Uitgewers, Johannesburg.

Botha, M.P., 2007, 'South African short film-making from 1980 to 1995: A thematic exploration', Communicatio: South African Journal for Communication Theory and Research 22(2), 51-56. https://doi.org/10.1080/02500169608537797

Botha, M.P., 2012, South African Cinema 1896-2010, Intellect, Bristal, UK.

Botha, M.P. \& Van Aswegen, A., 1992, Images of South Africa: The rise of the alternative film, RGN Publishers, Pretoria.

Bourdieu, P., 1986, 'The forms of capital', in J. Richardson (ed.), Handbook of theory and research for the sociology of education, pp. 241-258, Greenwood, Westport, CT.

Bourdieu, P., 1994, De regels van de kunst. Wording en structuur van het literaire veld, transl. R. van Hofstede, Van Gennep, Amsterdam.

Brink, A.P., 1991, Afrikaans: Op pad na 2000, D.F. Malherbe-gedenklesing 10, $15 \mathrm{Mei}$ 1991, Universiteit van die Oranje-Vrystaat, Bloemfontein

Buursink, M., Hupperetz, K., Lichter, E., De Roo, K. \& Schönau, W., 1978, De wetenschap van het lezen. Tien jaar theorie der literaire receptie, Assen, Van Gorcum, Amsterdam.

Coetzee, J., 1985, 'Lineal consciousness in the farm novels of C.M. van den Heever', Tijdschrift voor Nederlands en Afrikaans 1/2, 49-75.

Coetzee, J.M., 1988, White writing: On the culture of letters in South Africa, Yale University Press, New Haven, CT.

Davies, J., 1989, 'SA film: A brief history', ADA 6, 32-33.

Davis, P., 1996, In darkest Hollywood: Exploring the jungles of South Africa, Ohio University Press, Columbus, $\mathrm{OH}$.

Even-Zohar, I., 1990, 'Polysystem studies', Poetics Today 11(1), 1-94.

Fish, S., 1989, Doing what comes naturally. Change, rhetoric, on the practice of theory in literary and legal studies, Duke University Press, Durham.

Fokkema, D.W. \& Kunne-Ibsch, E., 1977, Theories of literature in the twentieth century, C. Hurts \& Co, London.

Foucault, M., 1970, The order of things. An archaeology of the human sciences, Tavistok, London.

Foucault, M., 1972, The archaeology of knowledge, Pantheon Books, New York.

Foucault, M., 1994, 'Nietzsche, genealogy, history', in J.D. Faubion (ed.), Miche Foucault. aesthetics, method and epistemology, pp. 369-391, Penguin, London.

Geboortegrond, 1946 [film] Directed by Pierre de Wet, African Films, South Africa

Giliomee, H., 2004, Die Afrikaners. 'n Biografie, Tafelberg, Kaapstad.

Giliomee, H., 2016, Historikus Hermann Giliomee. 'n Outobiografie, Tafelberg, Kaapstad.

Hall, S. (ed.), 1997, Representation. Cultural representations and signifying practises, Sage, Thousand Oaks, CA.

Hans die skipper, 1952 [film], Directed by Bladon Peake, AFP, South Africa

Iser, W., 1978, 'In het licht van de kritiek', in M. Buursink, K. Hupperetz, E. Lichter, K. De Roo \& W. Schönau (eds.), De wetenschap van het lezen. Tien jaar theorie der literaire receptie, pp. 174-189, Assen, Van Gorcum, Amsterdam.

Jacobs, E.M., 2015, 'Die posisie van swart skrywers van Afrikaanse prosa in die Afrikaanse prosasisteem sedert 1992', Ongepubliseerde D Litt-proefskrif, Universiteit van Pretoria, Pretoria.

Jameson, F., 2013, The antinomies of realism, Verso, London.

Jauss, H.R., 1978, 'Literatuurgeschiedenis als een provocatie voor de literatuurwetenschap', in M. Buursink, K. Hupperetz, E. Lichter, K. De Roo \& W.
Schönau (eds.), De wetenschap van het lezen. Tien jaar theorie der literaire receptie, pp. 1-28, Assen, Van Gorcum, Amsterdam.

Katz, D. \& Kahn, R.L., 1966, The social psychology of organizations, Wiley, New York.

Koorts, L., 2014, D.F. Malan en die opkoms van Afrikaner-nasionalisme, Tafelberg, Kaapstad.

Le Roux, A.I. \& Fourie, L., 1982, Filmverlede: Geskiedenis van die Suid-Afrikaanse speelfilm, Universiteit van Suid-Afrika, Pretoria.

Lotman, J., 1972, Die Struktur literarischer Texte, transl. R.-D. Keil, Fink, München.

Malherbe, D.F., 1929 [1952, 18e uitg.], Hans-die-Skipper, Nasionale Boekhandel Beperk, Kaapstad.

Montrose, L.A., 1989, 'Professing the renaissance: The poetics and politics of culture', in H.A. Veeser (ed.), The new historicism, pp. 15-36, Routledge, New York.

Nairn, T., 2013, Frontiers: A re-evaluation, Our Kingdom, 12 March, viewed 14 August 2016, from http://www.opendemocracy.net/ourkingdom/tom-nairn/frontiersre-evaluation

Pratt, M.L., 1977, Towards a speech act theory of literary discourse, Indiana University Press, Bloomington, IN.

Riley, E.J., 2012, 'From Matieland to Mother City: Landscape, identity and place in feature films set in the Cape Province 1947-1989', PhD, University of Cape Town, Cape Town.

Rose, G., 2007, Visual methodologies. An introduction to the interpretation of visual materials, Sage, London.

Rosenstone, R.A., 1995, Visions of the past: The challenge of film to our idea of history, Harvard University Press, Cambridge, MA.

Said, E., 2013, 'Introduction', in E. Auerbach (ed.), Mimesis. The representation of reality in Western literature. With a new introduction by Edward Said, Fiftieth Anniversary edn., pp. i-xxiv, Princeton University Press, Princeton, NJ.

Schmidt, S.J., 1992, 'Conventions and literary systems', in E. Ibsch, D. Schram \& G. Steen (eds.), Empirical studies of literature. Proceedings of the second EGELConference, Amsterdam 1989, pp. 413-424, Rodopi, Amsterdam.

Senekal, B., 2012, 'Die Afrikaanse literêre sisteem: 'n Eksperimentele benadering met behulp van Sosiale-netwerk-analise', LitNet Akademies 9(3), 614-638.

Sheffy, R., 1997, 'Models and habituses: Problems in the idea of cultural repertoires', Canadian Review of Comparative Literature 24, 35-47.

Speller, J.R.W., 2011, Bourdieu and Literature, Open Book Publishers, viewed from http://www.openbookpublishers.com

Tomaselli, K.G., 1979, The South African film industry, ASI Communication Number 7 2de Uitgawe, ASI University of the Witwatersrand, Johannesburg.

Tomaselli, K.G., 1988, The cinema of apartheid: Race and class in South African film, Smyrna Press, New York.

Tomaselli, K.G., 2006, Encountering modernity. Twentieth century South Africa cinema, Rozenberg Publishers, Amsterdam.

Van Coller, H.P., 2005, 'Die Afrikaanse prosa se peregrinasie van die plaas na die stad', in A.W. Oliphant \& H. Roos (eds.), Worlds, (Wo)man, World. Essays on Literature, pp. 56-93, University of South Africa, Pretoria.

Van Coller, H.P., 2006, 'Die representasie van plaas, dorp en stad in die Afrikaanse prosa', Stilet XVIII(1), 90-121.

Van Coller, H.P., 2009, Tussenstand. Literêre opstelle, Van Schaik Ultgewers, Pretoria.

Van der Merwe, Carel. 2015. Donker stroom: Eugène Marais en die Anglo-Boereoorlog, Tafelberg, Kaapstad.

Van Gennep, A., 1996, 'Territorial passage and classification of rites', in R.L. Grimes (ed.), Readings in ritual studies, pp. 529-536, Preason, Upper Saddle River, NJ.

Van Nierop, L., 2016, Daar doer in die fliek. 'n Persoonlike blik op die geskiedenis van die Afrikaanse rolprent, Protea Boekhuis, Pretoria.

Verdaasdonk, H., 1997, 'Op de grens van literatuurwetenschap: Hugo Verdaasdonk', in J. Goedegebuure \& O. Heynders (eds.), Literatuurwetenschap in Nederland. een vakgeschiedenis, pp. 119-134, Amsterdam University Press, Amsterdam.

Von Bertalanffy, L., 1968, General systems theory: Foundations, development, applications, George Braziller, New York.

Wellek, R., 1970, Discrimination. Further concepts of criticism, Yale University Press, New Haven, CT.

Wilden, A., 1987, Man and women, war and peace. The strategist's companion, Routledge \& Kegan Paul, New York. 